\title{
Mechanisms and models of TDP-43 proteinopathies
}

\author{
Leonard Petrucelli \\ From 2011 International Conference on Molecular Neurodegeneration \\ Shanghai, China. 22-24 September 2011
}

\section{Background}

Abnormal distribution, modification and aggregation of transactivation response DNA-binding protein 43 (TDP43) are the hallmarks of multiple neurodegenerative diseases, especially frontotemporal lobar degeneration with ubiquitin-positive inclusions (FTLD-U) and amyotrophic lateral sclerosis (ALS).

\section{Results}

To explore the pathogenic properties of mutant forms of TDP-43, we generated and characterized two mouse lines expressing human TDP-43 carrying the M337V mutation (hTDP-43 ${ }_{\mathrm{M} 337 \mathrm{~V}}$ ). We found hTDP-43 $3_{\mathrm{M} 337 \mathrm{~V}}$ was expressed primarily in the nuclei of neurons in the brain and spinal cord, intranuclear and cytoplasmic phosphorylated TDP43 aggregates were frequently detected, and the levels of TDP-43 LMW products of $\sim 25 \mathrm{kDa}$ and $\sim 35 \mathrm{kDa}$ species were also increased. Overexpression of hTDP- $43_{\mathrm{M} 337 \mathrm{~V}}$ dramatically down regulated the levels of mouse TDP-43 (mTDP-43) protein and RNA, indicating TDP-43 levels are tightly controlled in mammalian systems. TDP$43_{\mathrm{M} 337 \mathrm{~V}}$ mice displayed reactive gliosis, widespread ubiquitination, chromatolysis, gait abnormalities, and early lethality. Abnormal cytoplasmic mitochondrial aggregates and abnormal phosphorylated tau were also detected in the mice.

\section{Conclusion}

While overexpression of hTDP-43 in wild-type TDP-43 and TDP- $43_{\mathrm{M} 337 \mathrm{~V}}$ mouse models produces similar phenotypes, our results suggest that overexpression of the hTDP- $43_{\mathrm{M} 337 \mathrm{~V}}$ can cause neuronal dysfunction due to its effect on a number of cell organelles and proteins, such as mitochondria and TDP-43, that are critical for neuronal activity.

Mayo Clinic Jacksonville, USA
Published: 7 February 2012

doi:10.1186/1750-1326-7-S1-L19

Cite this article as: Petrucelli: Mechanisms and models of TDP-43 proteinopathies. Molecular Neurodegeneration 2012 7(Suppl 1):L19.
Submit your next manuscript to BioMed Central and take full advantage of:

- Convenient online submission

- Thorough peer review

- No space constraints or color figure charges

- Immediate publication on acceptance

- Inclusion in PubMed, CAS, Scopus and Google Scholar

- Research which is freely available for redistribution
() Bïomed Central

\section{() Biomed Central}

